\title{
Design of Micro Hydro Turbine for Domestic Energy Generation
}

\author{
Tunji John Erinle' ${ }^{1}$, Samuel Omojola Ejiko² ${ }^{2}$ Dayo Hephzibah Oladebeye ${ }^{3}$ \\ Lecturer III, Mechanical Engineering, The Federal Polytechnic, Ado-Ekiti, Ekiti State, Nigeria ${ }^{1}$ \\ Senior Lecturer, Mechanical Engineering, The Federal Polytechnic, Ado-Ekiti, Ekiti State, Nigeria ${ }^{2}$ \\ Chief Lecturer, Mechanical Engineering, The Federal Polytechnic, Ado-Ekiti, Ekiti State, Nigeria ${ }^{3}$
}

\begin{abstract}
The demand for electricity in developing country is alarming. The national grid power supply sources are insufficient and are not distributed effectively, hence the need to design and develop alternative source of power supply that can be harness locally. In this work a micro water turbine design was presented that could be used in laminar (low) flow to produce electricity using water storage overhead reservoir tank as a source of water couple with generators. The flow of water has kinetic energy to turn water turbine for the production of electricity. The energy produce is clean and does not cause global warming. The water turbine was design and model using SolidWorks engineering drawing software. The formulae for the calculation of flow and capacity parameter were highlighted. The water would flow from the water reservoir tank at a speed range of $3 \mathrm{~m} / \mathrm{s}$ to $5 \mathrm{~m} / \mathrm{s}$ to turn the water turbine. The flow rate of water from the jet would hit the cup on the runner causes the turbine to rotate due to the pressure by the flow of the water with 16 cups. The turbine would produce a runner rotation range of $5 \mathrm{rpm}$ to $100 \mathrm{rpm}$ with a torque of $3350 \mathrm{Nm}$. The water turbine could generate a power up to $35 \mathrm{~kW}$ and the water recycled into the overhead reservoir tank via water pump. The water pump will be powered by the electrical energy generated from the coupled generator to the water turbine. This will bring about the optimization of available water sources utilization and the production of power higher efficiency. The longevity of hydroelectric power plants makes it economically viable for the generation of electricity.
\end{abstract}

Keywords: Alternate Energy, Energy Demand, Global Warming, Hydroelectric, Water Turbine

\section{INTRODUCTION}

Turbine is any of various devices that convert the energy in a stream of fluid into mechanical energy. The conversion is generally accomplished by passing the fluid through a system of stationary passages or vanes that alternate with passages consisting of finlike blades attached to a rotor. By arranging the flow so that a tangential force, or torque, is exerted on the rotor blades, the rotor turns, and work is extracted [1]. Turbines can be classified into four general types according to the fluids used as water, steam, gas, and wind. Although the same principles apply to all turbines, their specific designs differ sufficiently to merit separate descriptions [2]. Water turbine is a rotary machine that converts kinetic energy and potential energy of water into mechanical work. Water turbines may be defined as prime movers that transform the kinetic energy of the falling water into mechanical energy of rotation and whose primary function is to drive an electric generator. One cubic meter of water can give about 9800 Joules of mechanical energy for every meter it descends and a flow of a cubic meter per second in a fall of 1 meter can provide $9800 \mathrm{~W}$ of power [3]. [4] studied on hydroelectric power plant design and a computer program was developed named Hydro Electric Plant Specification. This computer software was used for the rapid determination of plant specifications for different dams.

[5] reported that household in this contemporary time uses electricity for domestic comfort. The researcher stated that most functions of our society were based on the use of energy. It was concluded that elaborate networks of energy supply had been developed in the last three centuries in which electricity was fed into communities by the transmission lines of the electric grid at high voltage.

According to the [5] stated that water cycle occurred naturally and this resulted to rainfall which transferred millions of tons of water annually to high elevations with significant potential energy. The river that flows on the planet carry the very high amounts of potential and kinetic energy, which currently turn the turbines of several hydroelectric power plants and have the capability to provide at least $25 \%$ of the total electric energy demand of the planet. 


\title{
IARJSET \\ International Advanced Research Journal in Science, Engineering and Technology
}

\author{
Vol. 7, Issue 4, April 2020
}

The commonly used turbine is Pelton wheel type, this turbine uses spoon shaped buckets to harness the energy of failing water. It consists of a rotor equipped with buckets along the whole periphery of the turbine. The buckets are of elliptical shape. The quantity of water discharged by the nozzle can be controlled by controlling the nozzle's opening by means of needle placed in the tip of the nozzle [6;7].

A water turbine uses the potential energy resulting from the difference in elevation between an upstream water reservoir and the turbine exit water level (the tailrace) to convert this so-called head into work. Today, the primary use of water turbines is for electric power generation. Now they are mostly used for electric power generation. Water turbines are mostly found in dams to generate electric power from water potential energy $[8 ; 2]$.

The earliest known water turbines date to the Roman Empire. The horizontal water wheel with angled blades was installed at the bottom of a water-filled, circular shaft. The water from the mill-race entered the pit tangentially, creating a swirling water column which made the fully submerged wheel act like a true turbine $[9 ; 10 ; 11]$. The water wheel operation from converting the potential to kinetic energy as shown in Fig. 1.

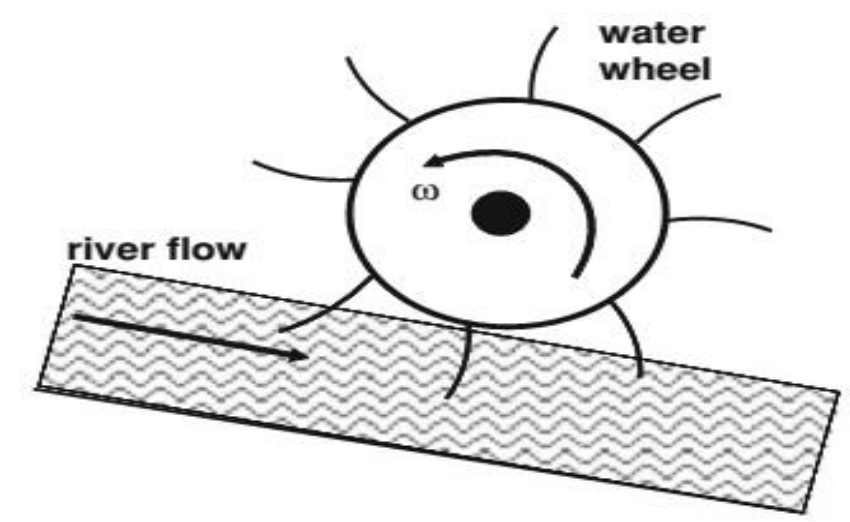

Fig. 1: Operation of a water wheel (Efstathios, 2012)

The precise shape of water turbine blade is a function of the supply pressure of water, and the type of impeller selected. In an impulse turbine the potential energy or the head of water is first converted into kinetic energy by discharging water through a carefully shaped nozzle. The jet discharged into air is directed onto curved buckets fixed on the periphery of the runner to extract the water energy and convert it to useful work. Impulse turbines change the velocity of a water jet [7].

[12] worked on spillage impulse water turbine and presented that flood water in the spillway can be effectively utilized for electricity generation. Type of impulse turbines as shown in Fig. 2. Currently, there was advancement on green energy technology and easy to get a generator with the right specification for micro-hydro power plant development [13].

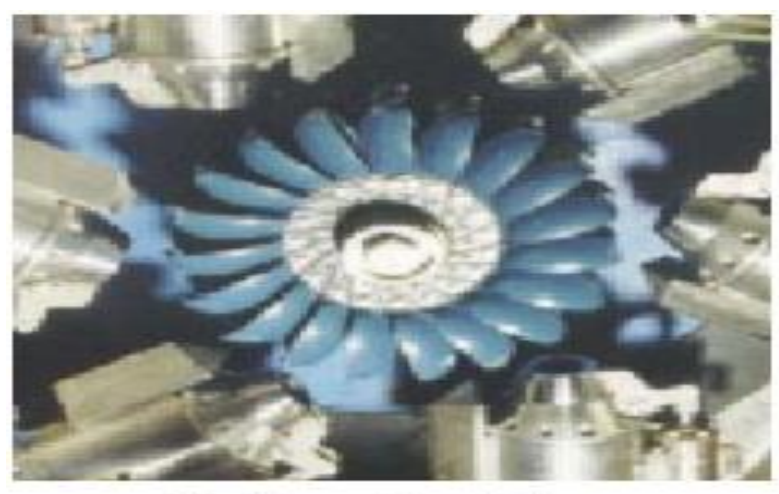

Pelton turbine

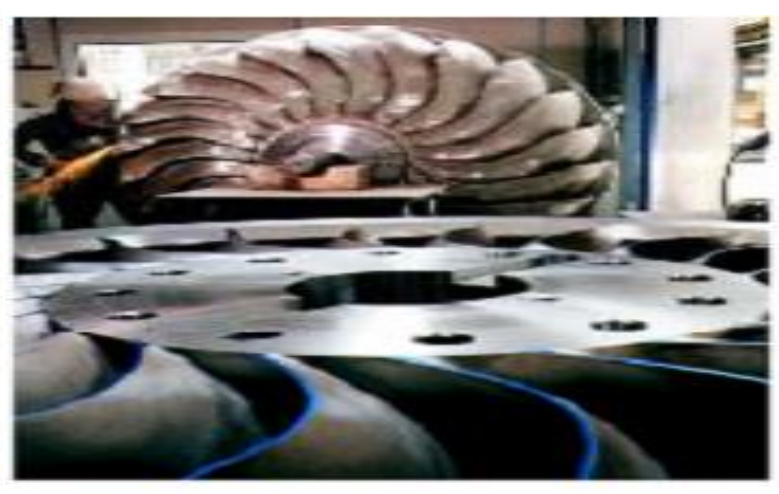

Turgo impulse turbine

Fig. 2: Imupulse Turbines [3]

[12] studied on comparative assessment of savonius water turbine with conventional savobius wind turbine. The result that was obtained suggest that the savonius water turbine with the highest coefficient of power $(\mathrm{Cp})$ value of 0.343 is dominant over savonius wind turbine. Pelton turbines are best suited for high head and low flow sites. [15] investigated that a propeller-type hydrokinetic turbine was as a solution for a portable micro-hydrokinetic turbine. The turbine is to 


\section{IARJSET \\ International Advanced Research Journal in Science, Engineering and Technology}

Vol. 7, Issue 4, April 2020

utilize the potential and kinetic energy of a conventional water supply by means of access to streams and small waterfalls [16; 17]. Depending on water flow and design, Pelton wheels can operate with heads as small as 15 meters and as high as 1800 meters. As the height of fall increases, less volume of water can generate same power. Turbine selection is based on the available water head, and less so on the available flow rate. In general, impulse turbines are used for high head sites, and reaction turbines are used for low head sites [18; 19]. This alternate source of energy for house hold electric energy requirements are very essential and also important that this source should be portable and easily operated by common man [17]. This water turbine under investigation is designed for domestic hydroelectric generation.

\section{METHODOLOGY}

The solid works engineering design drawing software was used to draw the isometric and orthographic view of the water turbine for the domestic electric energy generation. The pelton type of water turbine was adopted for the design. The drawing involved the Case, Runner, Shaft, Bearings (rolling type), water pipe, water tanks, water turbine, water pump, metal base and metal support.

The material of the runner and buckets should be chosen according to the head material of the runner and also the buckets according to the head, stresses, content of sand in the water and other strain factors. For the large turbines the main strain factors are cavitation, sand erosion and cycle fatigue. Limitations however is that bucket shape always will be a compromise between a hydraulically ideal and a structural optimum design. The shape of the buckets is decisive for the efficiency of the turbines [3].

\section{A. Description of the Micro Water Turbine}

[3] design initiative was adopted in which the runner disc would be fastened to the shaft by bolts and nuts. The turbine shaft of vertical micro water turbine contained an integral flange at both ends. A hole was provided centrally through the whole length of the shaft. Journal and thrust bearings are provided with circulating grease to carry the heat dissipated by the shaft and bearings. The distributor pipe is designed to provide an acceleration of the water flow through the water tank towards the main injector or jet at the turbine inlet. This design is advantageous, because it by contributes in keeping a uniform velocity profile of the flow. The injection of the water flow to the runner cups or buckets as shown in Fig. 3 .

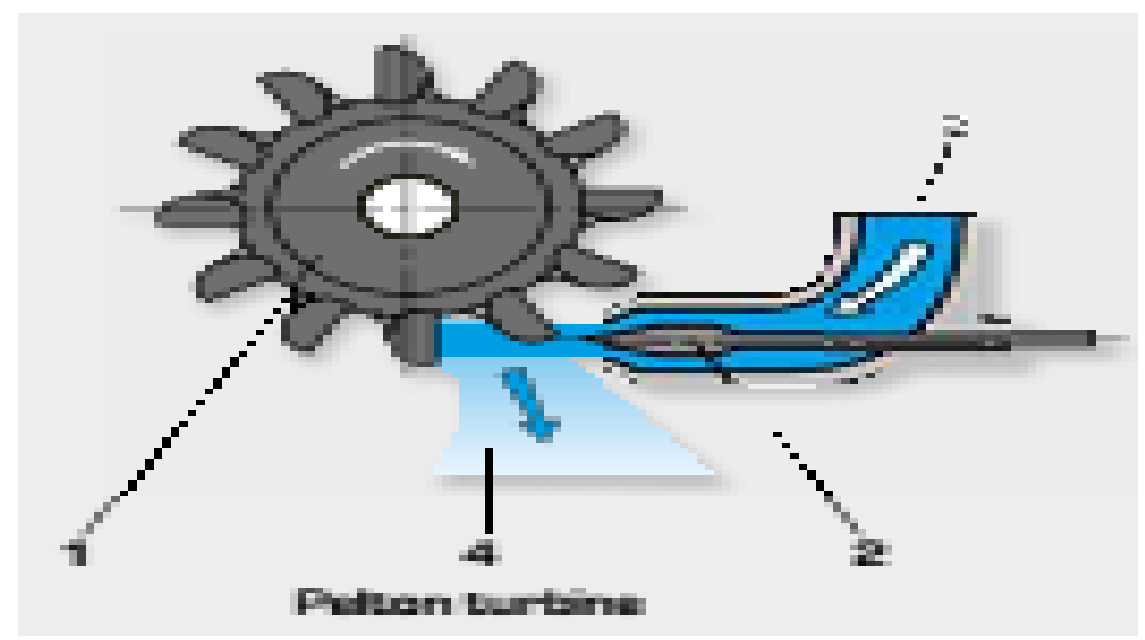

Fig. 3: Water Turbine [20]

\section{B. Micro Water Turbine Specifications Parameters}

The specification parameters for the designed micro water turbine as follows:

Gross head: 10 to $15 \mathrm{~m}$

Net head: $10 \mathrm{~m}$

Jet Velocity: $3-5 \mathrm{~m} / \mathrm{s}$

Speed: 5 to $100 \mathrm{rpm}$

Jet diameter: $5 \mathrm{~mm}$

Pitch diameter of the wheel: $35 \mathrm{~mm}$ 


\section{International Advanced Research Journal in Science, Engineering and Technology}

Vol. 7, Issue 4, April 2020

Power: $35 \mathrm{~kW}$

\section{C. $\quad$ Specific Energy of Micro Water Turbine}

[3] stated that the specific energy of a hydropower system is the quantity of potential and kinetic energy which one kilogram of the water delivers when passing through the system from an upper to a lower part of the water reservoir. The expression of the specific water energy is $\mathrm{J} / \mathrm{kg}$. The pictorial view of runner with cups as shown in Fig. 4.

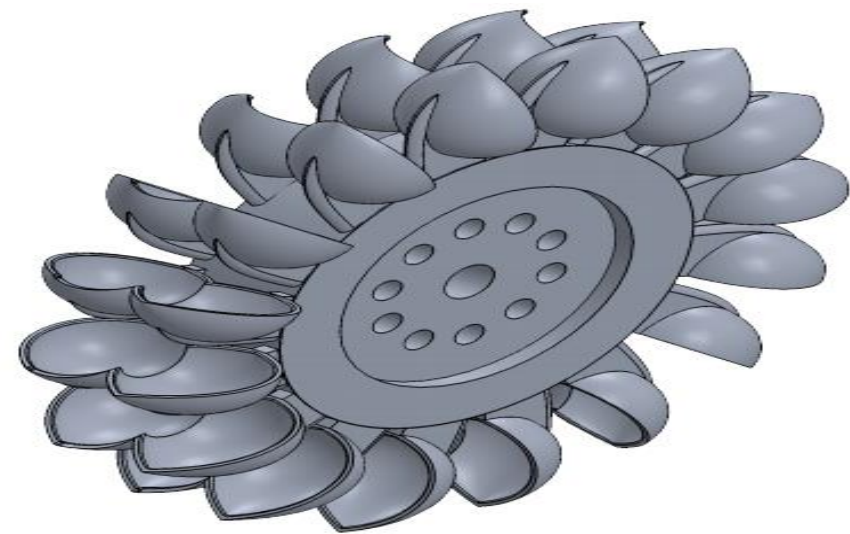

Fig. 4: Runner with Cups

[3] gave some foundational idea on hydraulic turbine principle which was adopted in the design analysis of the micro water turbine for the domestic power generation. The idea was also supported by [20].

\section{DESIGN ANALYSIS OF THE MICRO WATER TURBINE}

Gross Head is the difference between the head race and tail race level when there is no flow and also termed as static head. The difference between the level of the upper reservoir $Z_{\text {res }}$ and the level of the tail water $Z_{\text {tw }}$ is defined as the gross head.

Effective Head is the head available at the inlet of the turbine. The effective head above the turbine. It is obtained by considering all losses. It means the gross head minus total loss

Equation 1 to 21 were used for the design analysis of the micro water turbine according to $[21 ; 5 ; 3 ; 20]$.

$\mathrm{H}_{\mathrm{g}}=\mathrm{Z}_{\mathrm{res}}-\mathrm{Z}_{\mathrm{tw}}$

The corresponding gross specific hydraulic energy

$\mathrm{E}_{\mathrm{g}}=\mathrm{g} \mathrm{H}_{\mathrm{g}}$

$\mathrm{E}_{\mathrm{g}}$ is the gross specific energy; $\mathrm{H}_{\mathrm{g}}$ is the gross head; $\mathrm{g}$ is the acceleration of gravity.

The difference in specific energy from inlet to outlet of the runner of the water turbine could be expressed by equation 3 . For still water, net head is the difference in height between the inlet and outlet surfaces. Moving water has an additional component added to account for the kinetic energy of the flow. The total head equals the pressure head plus velocity head as given in equation 5. The effective head of the turbine could be expressed as the net head as given in equation 7 .

The corresponding net specific hydraulic energy

$\mathrm{E}_{\mathrm{n}}=\mathrm{g} \mathrm{H}_{\mathrm{n}}$

The net head of the turbine

$H_{n}=\frac{E_{n}}{g}$

$\mathrm{H}_{\mathrm{n}}=\mathrm{h}_{\mathrm{p}}+\frac{\mathrm{v}^{2}}{2 \mathrm{~g}}$

$\mathrm{H}_{\mathrm{n}}=\mathrm{H}_{\mathrm{g}}-\frac{\mathrm{E}_{\mathrm{L}}}{\mathrm{g}}$

$\mathrm{H}_{\mathrm{n}}=\mathrm{H}_{\mathrm{g}}-\mathrm{H}_{\mathrm{L}}$

$\mathrm{h}_{\mathrm{p}}$ is the piezometric head above tail water level or pressure head $\left(\frac{\mathrm{P}_{\mathrm{B}}}{\mathrm{\rho g}}\right) ; \frac{\mathrm{V}^{2}}{2 \mathrm{~g}}$ is the velocity head the velocity head; $\frac{\mathrm{E}_{\mathrm{L}}}{\mathrm{g}}$ is specific hydraulic energy loss; $H_{n}$ is the net head; $H_{L}$ is the total loss. 


\section{International Advanced Research Journal in Science, Engineering and Technology}

Vol. 7, Issue 4, April 2020

\section{A. Power of the Water Flow}

The total power recovered from the river flow as given in equation 8 . The torque on the water wheel is denoted by $\mathrm{T}$ and the angular velocity by $\omega$.

$\mathrm{P}=\mathrm{T} \omega$

8

[5] reported that the harnessing of hydroelectric power relies on the difference of the potential energy of the water and the mass flow rate of the water flow. The maximum amount of power that may be produced by a stream of water flowing at mass flow rate $\dot{m}$; when it falls over a height by $\Delta \mathrm{H}$

$\mathrm{P}_{\max }=\dot{\mathrm{mg}} \mathrm{H}_{\mathrm{n}}$

When a water discharge, $\mathrm{Q}\left(\mathrm{m}^{3} / \mathrm{s}\right)$ passes through the water turbine, the delivered power is

$\mathrm{P}_{\mathrm{g}}=\rho \mathrm{Qg} \mathrm{H} \mathrm{H}_{\mathrm{g}}$

$\mathrm{P}_{\mathrm{g}}$ is the gross power of the turbine; $\rho$ is the density of the water; $\mathrm{Q}$ is the discharge.

\section{B. Velocity Triangle for Micro Water Turbine}

The velocity triangle and velocity diagram adopted for the micro water turbine as shown in Fig. 5 and 6.

(a) Ideal Fluid Velocities for Water Turbine

(b) Relative Velocities for Water Turbine

(c) Inlet and Exit Velocity Triangles for Water Turbine
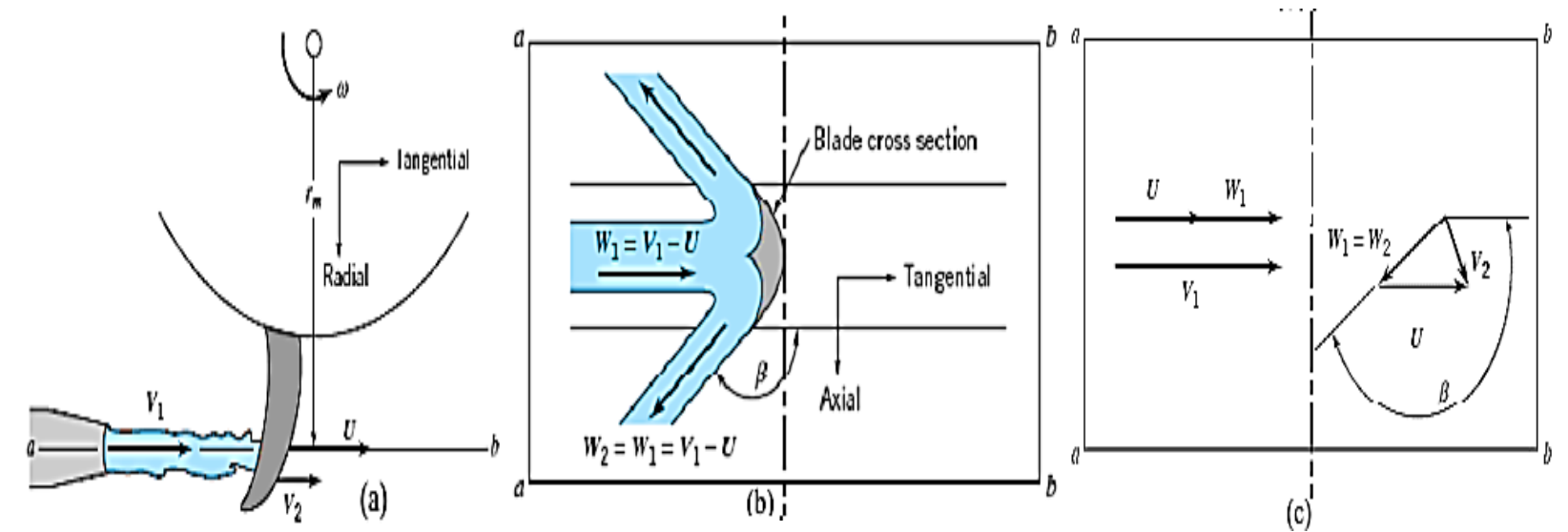

Fig. 5: Velocity Triangle for Pelton Water Turbine [3].

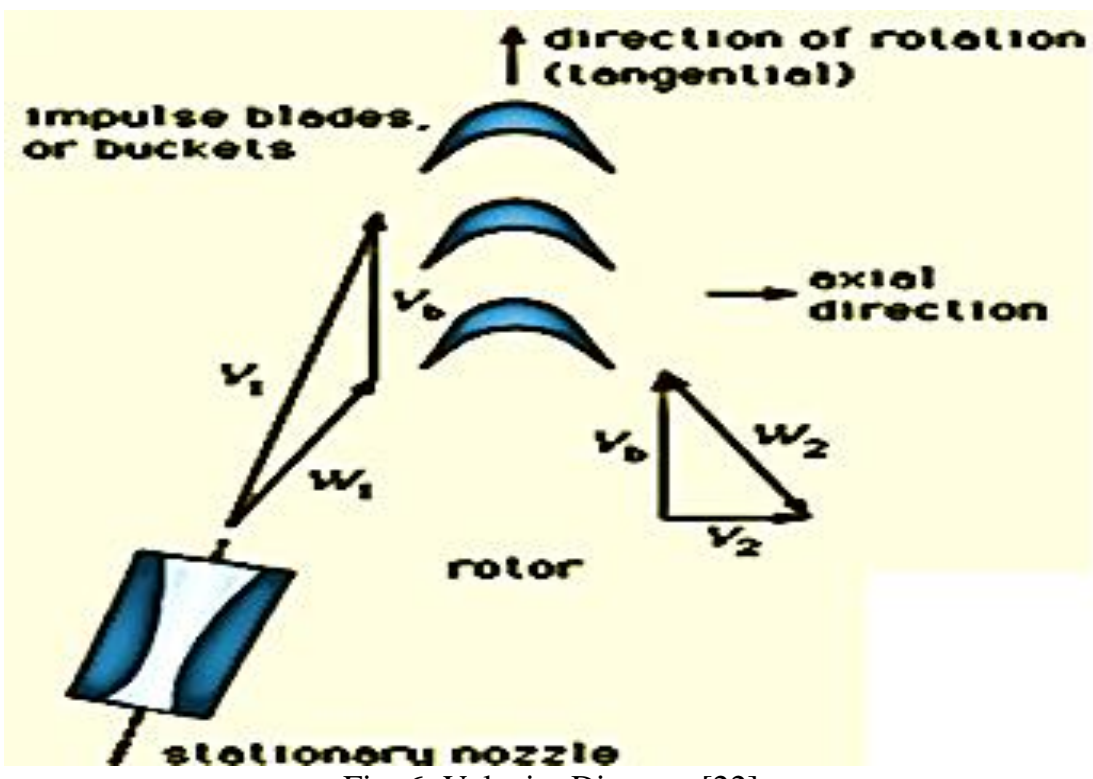

Fig. 6: Velocity Diagram [22]

$\mathrm{V}_{\mathrm{b}}$ is the Tangential velocity of blade; $\mathrm{V}$ is the Absolute velocity of fluid; $\mathrm{W}$ is the Velocity of fluid relative to blade. 


\section{International Advanced Research Journal in Science, Engineering and Technology}

Vol. 7, Issue 4, April 2020

\section{Selection of Turbine on the Basis of Specific Speed:}

The specific speed $\mathrm{N}_{\mathrm{S}}$ is the most important characteristic for water turbines. It is a measure of the ratio of water velocity to rotational speed. The selection could be base in term of power developed by the water turbine as given in equation 10 .

$\mathrm{N}_{\mathrm{S}}=\mathrm{N} \frac{\mathrm{P}^{\frac{1}{2}}}{\mathrm{H}^{\frac{5}{4}}}$

$\mathrm{N}_{\mathrm{S}}$ is the specific speed; $\mathrm{n}$ is in revolutions per minute; $\mathrm{P}$ is the output in watt; $\mathrm{H}$ is the head of water in metre. If $\mathrm{N}_{\mathrm{S}}$ ranges from 1 to 20, corresponding to high heads and low rotational speeds, impulse turbines are appropriate [2]. A distinction is made between low-speed turbines, where the water velocity is significantly higher than the peripheral speed, and high-speed turbines, where the situation is reversed as stated in equation 11 according to [20].

$\mathrm{N}_{\mathrm{S}}=\mathrm{N} \frac{\mathrm{Q}^{\frac{1}{2}}}{\mathrm{H}^{\frac{5}{4}}}$

$\mathrm{N}$ is the rotational speed, $\mathrm{Q}$ the flow rate and $\mathrm{H}$ the head of the water turbine. The ratios are made clear in the velocity triangle.

\section{Work Done for Micro Water Turbine:}

The actual work produced by the hydraulic turbine is lower than the maximum work because of the finite efficiency of the turbine, which is typically in the range $72-84 \%$ as given in equation 12 according to [5].

$\dot{\mathrm{W}}=\eta \dot{\mathrm{m} g H}$

$\eta$ is the efficiency of the turbine; $\dot{m}$ is the mass flow rate of the water; $\mathrm{H}$ is the head of water in metre; $g$ is the acceleration of gravity.

Tangential velocity at inlet of water turbine

$\mathrm{V}_{b l}=\mathrm{W}_{1}+\mathrm{V}$

Tangential velocity at outlet of water turbine

$\mathrm{V}_{\mathrm{b} 2}=\mathrm{W}_{2} \cos \beta+\mathrm{V}$

Velocity of fluid relative to blade does not change as it is deflected by the buckets. Assuming, $\mathrm{W}_{1}=\mathrm{W}_{2} ; \mathrm{V}_{1}=\mathrm{V}_{2}=\mathrm{V}$ $\mathrm{V}_{\mathrm{b} 2}-\mathrm{V}_{\mathrm{b} 1}=\left(\mathrm{V}-\mathrm{V}_{\mathrm{b} 1}\right)(1-\operatorname{Cos} \beta)$

\section{POWER AND TORQUE FOR MICRO WATER TURBINE}

This change in tangential component of velocity combined with torque and power equation gives

$\mathrm{T}_{\text {shaft }}=\dot{\mathrm{m}} \mathrm{r}_{\mathrm{m}}\left(\mathrm{V}_{\mathrm{b} 2}-\mathrm{V}_{\mathrm{b} 1}\right)=\dot{\mathrm{mr}}_{\mathrm{m}}\left(\mathrm{V}-\mathrm{V}_{\mathrm{b} 1}\right)(1-\operatorname{Cos} \beta)$

$\mathrm{V}=\omega \mathrm{r}_{\mathrm{m}}$

$\mathrm{P}_{\text {shaft }}=\mathrm{T}_{\text {shaft }} \omega=\dot{\mathrm{m}} \mathrm{V}\left(\mathrm{V}-\mathrm{V}_{\mathrm{b} 1}\right)(1-\operatorname{Cos} \beta)$

$\mathrm{P}=\rho \mathrm{Q}\left(\mathrm{V}_{2} \mathrm{~V}_{\mathrm{b} 2}-\mathrm{V}_{1} \mathrm{~V}_{\mathrm{b} 1}\right)$

$\mathrm{V}_{1}=\mathrm{V}_{2}=\mathrm{V}$ and $\left(\mathrm{V}_{\mathrm{b} 2}-\mathrm{V}_{\mathrm{b} 1}\right)=\mathrm{V}_{\mathrm{b}}$

$\mathrm{P}=\rho \mathrm{QV}\left(\mathrm{V}_{\mathrm{b} 2}-\mathrm{V}_{\mathrm{b} 1}\right)=\rho \mathrm{AV}^{2}\left(\mathrm{~V}_{\mathrm{b} 2}-\mathrm{V}_{\mathrm{b} 1}\right)$

$\mathrm{P}=\rho \mathrm{AV}^{2}\left(\mathrm{~V}_{\mathrm{b} 2}-\mathrm{V}_{\mathrm{b} 1}\right)=\rho \mathrm{AV}^{2}\left(\mathrm{~V}_{\mathrm{b} 2}-\mathrm{V}_{\mathrm{b} 1}\right)=\rho \mathrm{AV}^{2}\left(\mathrm{~V}_{\mathrm{b}}\right)$

When runner is at standstill $(\mathrm{V}=0)$, Power would be zero; when $\mathrm{V}=0.5 \mathrm{~V}_{\mathrm{b}}$, Power would be minimum; when $\mathrm{V}=\mathrm{V}_{\mathrm{b}}$, Power would be maximum.

Typical theoretical and experimental power and torque relation for a Pelton turbine as a function of bucket speed which was adopted for this present study. Euler turbine equation could be adopted to express the hydraulic efficiency.

According to the [21] presented that the hydraulic efficiency of a turbine excludes friction losses on the outside of the runner, leakage loss of water that does not pass through the runner blades and mechanical friction losses in which the hydraulic efficiency of a well-designed turbine is $98-99 \%$. The effects of friction could be determined by the Reynolds number as given in equation 21 according to [2] which reduces the hydraulic efficiency to a typically in the range $72-$ $84 \%$.

Reynolds number, $\operatorname{Re}=\frac{\text { density } \times \text { rotational speed } \times \text { runner diameter squared }}{\text { viscosity }}=\frac{\rho \times N \times D^{2}}{\mu}$

[20] presented that the turbine characteristic curve depicted the typical behaviour of a water turbine. The water turbine is preferably operated at the operating point (1), where it has the highest efficiency. The torque in a Pelton turbine corresponds to roughly half of the stall torque at point (3). The turbine speeds up to the runaway speed at point (2) when it is not under load. This over speed could be up to twice the design speed and may result in severe damage to the turbine. 


\section{International Advanced Research Journal in Science, Engineering and Technology}

Vol. 7, Issue 4, April 2020

A speed controller should be incorporate to prevent any damage by closing the distributor and throttling the water supply. The characteristic of water turbine parameter depicted as shown in Fig. 7.

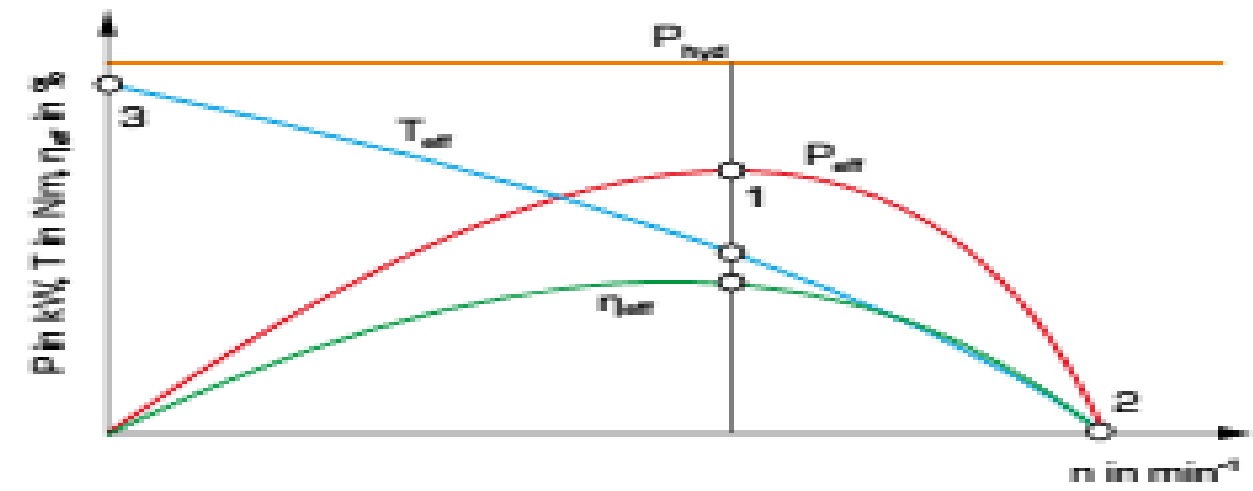

Spead-tonque characteristic of a water turtine

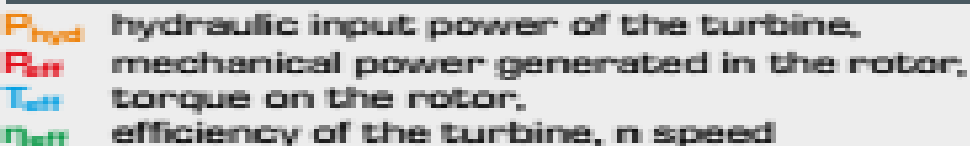

Thit aficiency of the turbine, $n$ spaed

Fig. 7: Speed -Torque Characteristic of Water Turbine [20].

\section{RESULTS AND DISCUSSIONS}

The results of the designed micro water turbine were presented in Fig. 8 to 10 . The power to be generated is $35 \mathrm{~kW}$, torque of $3350 \mathrm{Nm}$ and rotational speed range of $5 \mathrm{rpm}$ to $100 \mathrm{rpm}$. The water reservoir could maintain the water flow to the water wheel at a controlled rate, thus increasing the potential energy that may be converted to kinetic energy through the water turbine to turn the coupled generator to produce electric power.

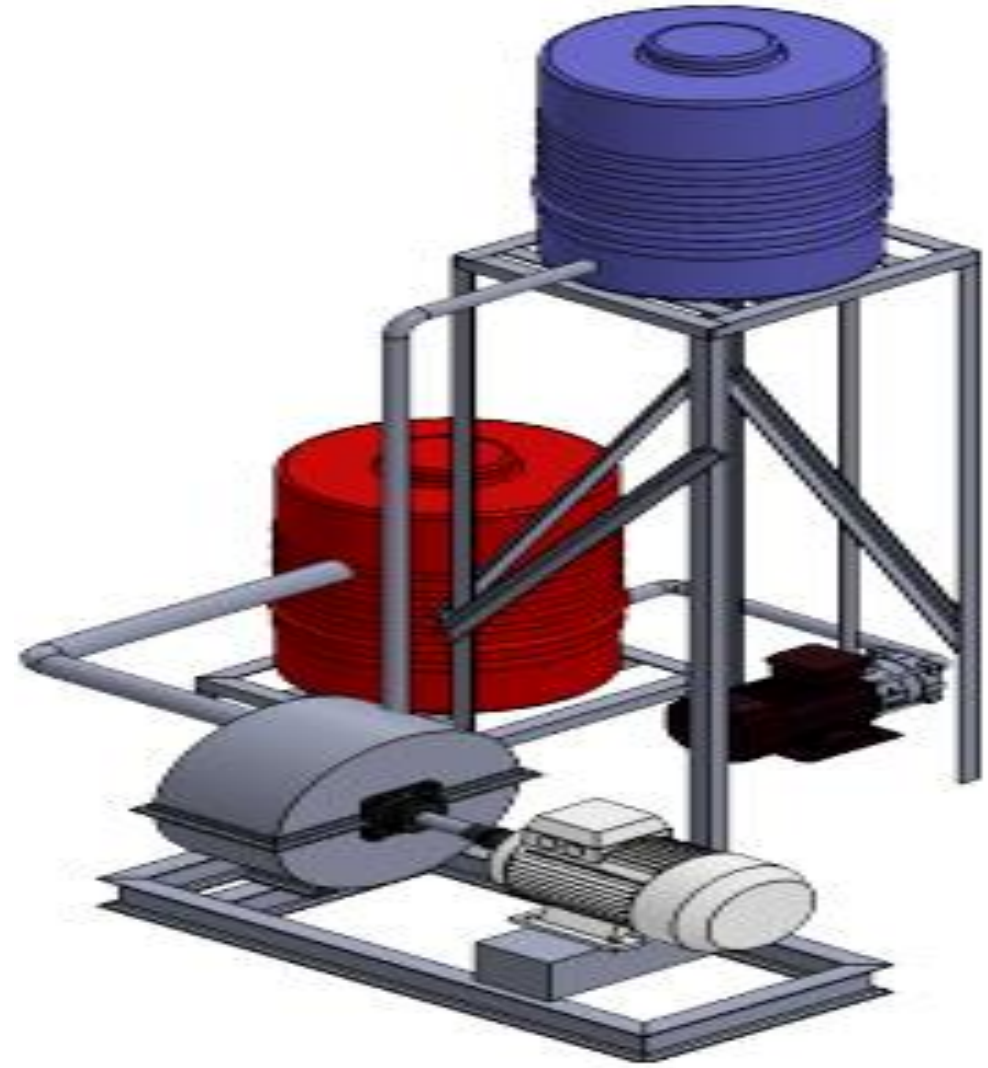

Fig. 9: Isomeric View of the Micro Water Turbine for Domestic Power Generation 


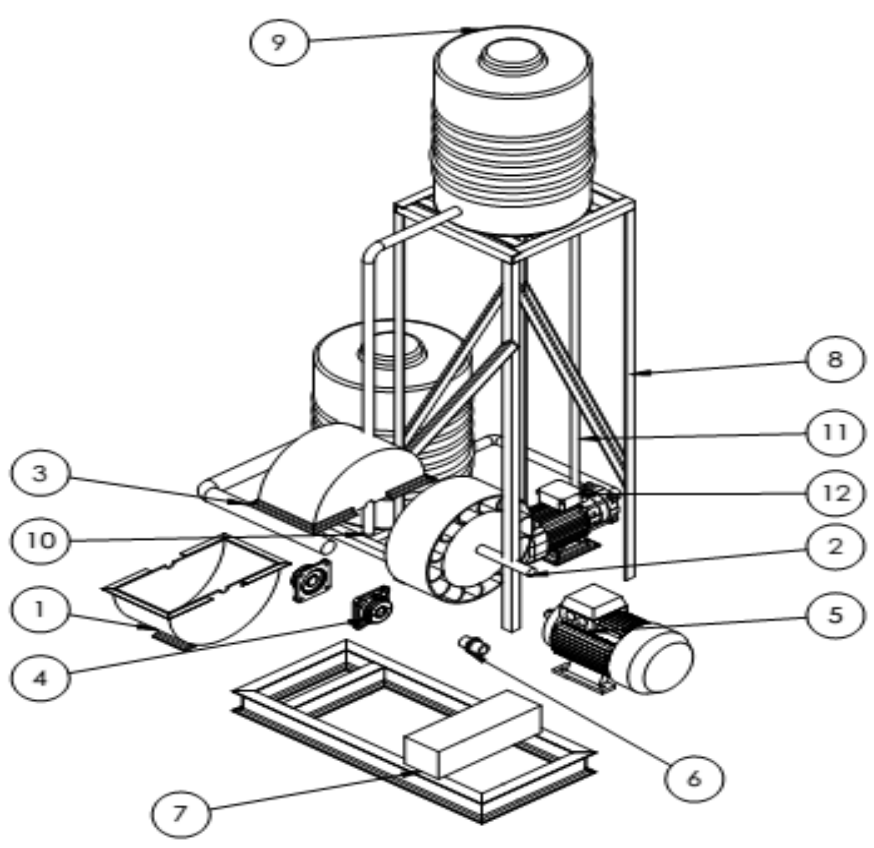

\begin{tabular}{|c|l|c|}
\hline $\begin{array}{c}\text { ITEM } \\
\text { NO. }\end{array}$ & \multicolumn{1}{|c|}{ PART NUMBER } & QTY. \\
\hline 1 & Bottom Half & 1 \\
\hline 2 & Turbine Blade & 1 \\
\hline 3 & Top Half & 1 \\
\hline 4 & $\begin{array}{l}\text { Rexnord-4 Bolf } \\
\text { Medium Duty Flange } \\
\text { Units MFCL2ON- } \\
\text { MFCL219N }\end{array}$ & 2 \\
\hline 5 & Alternator & 1 \\
\hline 6 & Coupling & 1 \\
\hline 7 & Frame & 1 \\
\hline 8 & Water Tank Stand & 1 \\
\hline 9 & Water Tank & 2 \\
\hline 10 & Pipe & 1 \\
\hline 11 & Pipe 2 & 1 \\
\hline 12 & Water pump & 1 \\
\hline
\end{tabular}

Figure 10: Exploded View of the Micro Water Turbine for Domestic Power Generation
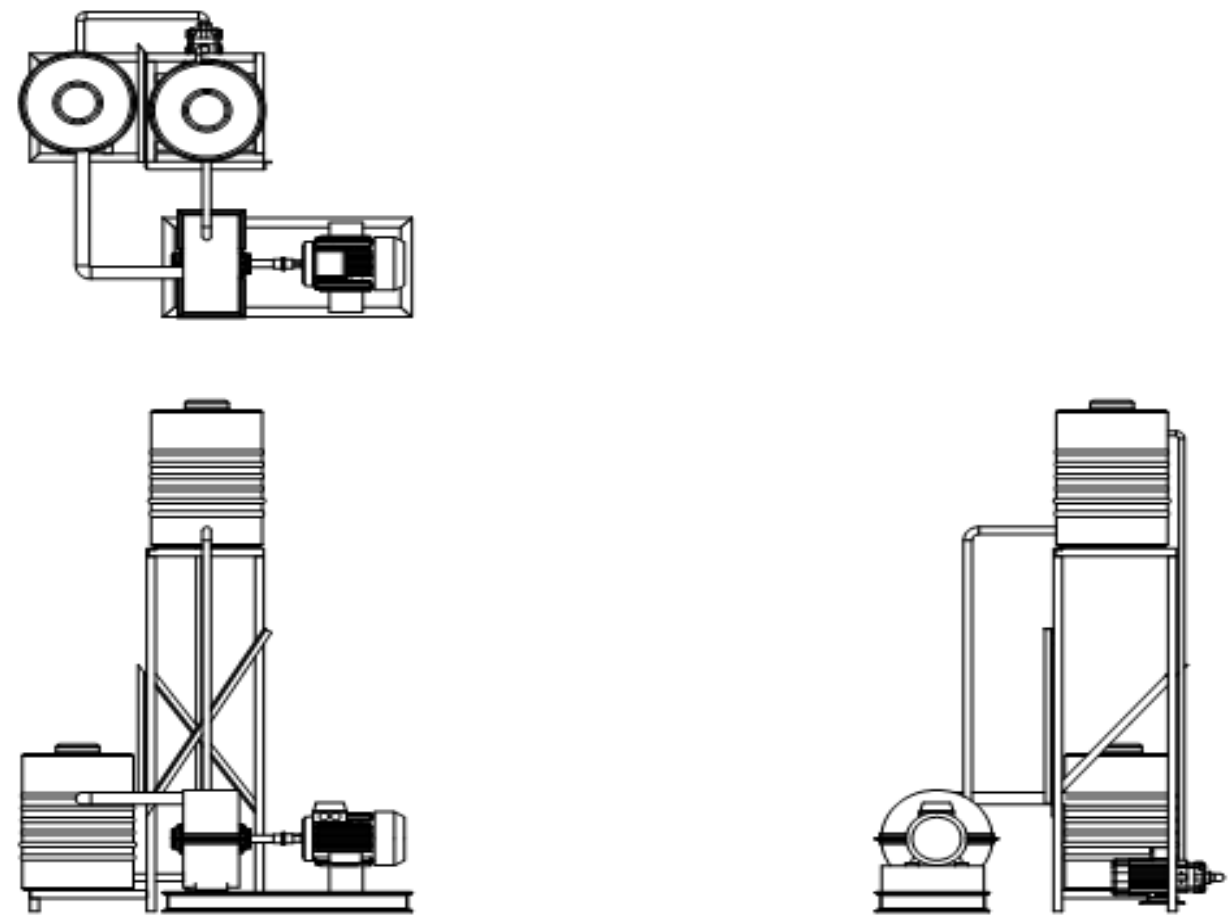

Fig. 11: Orthographic View of the Micro Water Turbine for Domestic Power Generation

\section{CONCLUSION}

It has been shown that the micro water turbine designed gives details analysis and pictorial view of how it takes to generate electric power for domestic used. The power to be generated is $35 \mathrm{~kW}$, torque of $3350 \mathrm{Nm}$ and rotational speed range of 5 to $100 \mathrm{rpm}$. This design could be adopted in generating meaningful electric power via household water tank reservoir. The typical turbine-generator could have $75 \%$ efficiency. 


\section{International Advanced Research Journal in Science, Engineering and Technology}

Vol. 7, Issue 4, April 2020

\section{REFERENCES}

[1]. Jean-Luc, A., Favio, D., and Christophe, C. (2015). Cross Flow Water Turbines: Harvest Technology. doi: 10.1051/rees/2016029. https://www.researchgate.net/publication/277994622.

[2]. Landis, F. (2013). Turbine. Encyclopædia Britannica. Encyclopædia Britannica Ultimate Reference Suite, Chicago, USA.

[3]. Nagpurwala, Q. H. (2016). Hydraulic Turbines, M. S. Ramaiah School of Advanced Studies.

[4]. Ejiko, S. O., Adubi, E. G. and Adewuyi, R. A. (2019). Hydroelectric Power Plant Design: A Case Study of Agric Livestock Investigation Centre Dam in Erinfun, Ekiti State. Adeleke University Journal of Engineering and Technology [AUJET] Vol. 2, No. 3, pp. 61-79. ISSN: 2714- 2450.

[5]. Efstathios, E. M. (2012). Alternative Energy Sources. Springer Heidelberg Dordrecht London New York. ISSN $1865-3529$ e-ISSN $1865-3537$. doi: 10.1007/978-3-642-20951-2. http://www.springer.com/series/8059.

[6]. Encyclopedia Britannica (2013). Turbine. Encyclopedia Britannica Ultimate Reference Suite, Chicago, USA.

[7]. Davis, C. V. and Sorensen, K. E. (1984). Handbook of Applied Hydraulics, 3rd Edition.

[8]. Donners, K., Waelkens, M. and Deckers, J. (2002). "Water Mills in the Area of Sagalassos: A Disappearing Ancient Technology", Anatolian Studies, 52, pp. 1-17, doi: 10.2307/3643076.

[9]. Wilson, A. (1995). "Water-Power in North Africa and the Development of the Horizontal Water-Wheel", Journal of Roman Archaeology, 8, pp. 499-510.

[10]. Fasol, K. H. (2002). "A Short History of Hydropower Control" (PDF). IEEE Control Systems Magazine, pp. 68-76.

[11]. Wikander, Ö. (2000). "The Water-Mill", in Wikander, Örjan (ed.), Handbook of Ancient Water Technology, Technology and Change in History, 2, Leiden: Brill, pp. 371-400, ISBN 90-04-11123-9.

[12].Chenghao, W. (2014). Spillway Impulse Water $\quad$ Turbine, Patent. doi:10.13140/RG.2.1.4031.9848. https://www.researchgate.net/publication/267156787.

[13]. Parea, R. R., Andrea, S. K., Yusri, A. M. A. and Abedneigo, C. R. (2018). Design of River Flow Floating Portable Micro-Hydro. International Journal of Engineering and Techniques, Vol. 4 Issue 1, pp.593-597, ISSN 2395-1303 http://www.ijetjournal.org.

[14]. Neelam, K. S., Agninitra, B. and Rahul, D. M. (2019). Comparative Assessment of Savonius Water Turbine with Conventional Savobius Wind Turbine. doi: 10-1115/GTINDIA 2019-2459. ASME 2019 Gas Turbine India Conference.

[15]. Schleicher, W. C. (2015). Design Optimization of a Portable Micro-Hydrokinetic Turbine, A Dissertation Presented to the Graduate and Research Committee of Lehigh University in Candidacy for the Degree of Doctor of Philosophy in Mechanical Engineering Lehigh University.

[16]. Damodhar, R., Mruthyunjaya, K. N., Naveen, K., Pavan. P. and Rakhesh, H. S. (2017). Design and Fabrication of Portable Water Turbine. International Research Journal of Engineering and Technology (IRJET). Vol. 4 Issue 6, pp.2584-2590, ISSN 2395-0056, ISSN $2395-0072$. www.irjet.net.

[17]. Pravin, O., Shubham, P., Tejas, P., Vaibhav, P. and Aadil, S. (2019). Design and Development of Portable Water Turbine. International Advanced Research Journal in Science, Engineering and Technology, IARJSET, Vol. 6, Issue 3, pp. 49-51, ISSN 2393-8021, ISSN 2394-1588. doi 10.17148/iarjset.2019.6309.

[18]. Rossi, C., Russo, F. and Russo, F. (2009). "Ancient Engineers' Inventions: Precursors of the Present". Springer. ISBN 904812252X.

[19]. Guevara-Stone, L. (2014). "How a small Spanish island became a renewable energy pioneer". greenbiz.com.

[20]. Gunt Hamburg (2020). Hydraulic Fluid Energy Machines, Basic Knowledge in Water Turbines.

[21]. Hermod, B. (2001): Hydraulic Turbines Design, Erection and Operation, Endringsdato.

[22]. Encyclopedia Britannica (1999). Turbine Velocity Diagram. Encyclopedia Britannica Ultimate Reference Suite, Chicago, USA.

\section{BIOGRAPHIES}

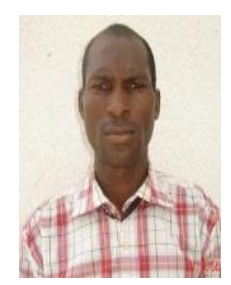

Tunji John Erinle is a Lecturer, Professional Mechanical Engineer and Researcher in the Department of Mechanical Engineering, The Federal Polytechnic, Ado_Ekiti, Ekiti State, Nigeria. He holds a Master in Engineering (M. Eng.) degree in Mechanical Engineering. He is a member of many Professional Society both national and international. His Scopus Author ID: 57214232158, Researcher ID: E-77522018 and Web of Science Researcher ID: AAL-3877-2020. The research interests are Renewable energy, Machine design, Corrosion, Materials characterization, Thermofluids, Mechatronics and Robotics.

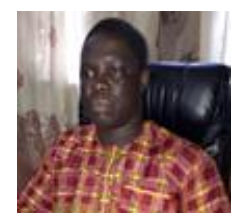

Samuel Omojola Ejiko is a Senior Lecturer in the Department of Mechanical Engineering, The Federal Polytechnic, Ado_Ekiti, Ekiti State, Nigeria. He holds a Doctor of Philosophy (Ph. D) degree in Mechanical Engineering. He is a member of many Professional Society both national and international. The research interests are in the areas of Renewable energy, Machine design, Mechatronics, Industrial and Production Engineering.

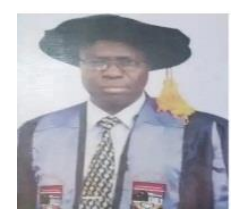

Dayo Hephzibah Oladebeye is a Chief Lecturer in the Department of Mechanical Engineering, The Federal Polytechnic, Ado_Ekiti, Ekiti State, Nigeria. He holds a Doctor of Philosophy (Ph. D) degree in Mechanical Engineering. He is a member of many Professional Society both national and international. The research interests are in the areas of Renewable energy, Machine design, Robotics, Industrial and Production Engineering. 